\title{
A perkután nervus tibialis posterior stimuláció (PTNS) a túlmú- ködő hólyagszindróma kezelésében: első hazai tapasztalatok
}

Pytel Ákos dr.

Pécsi Tudományegyetem, Klinikai Központ, Urológiai Klinika, Pécs (igazgató: Szántó Árpád dr.)
Levelezési cím: Dr. Pytel Ákos

PTE KK, Urológiai Klinika

7621 Pécs, Munkácsy M. u. 2.

e-mail:pyteljun@freemail.hu

\section{ÖSSZEFOGLALÁS}

Bevezetés: A túlműködő hólyagszindróma számos okra visszavezethető tünetegyüttes. A különböző irányelvek egységesek abban a tekintetben, hogy az életmódbeli változásokra, viselkedésterápiára és gyógyszeres terápiára refrakter esetekben javasolt invazív, másod- (harmad) vonalbeli kezelések alkalmazása. Ide tartoznak a különböző neuromodulációs eljárások, többek között a perkután nervus tibialis posterior stimulálása. Irodalmi adatok alapján a beavatkozás hatékony túlmúködő hólyagszindróma kezelésében. Jelen közlemény célja - elsőként a hazai irodalomban - a kezeléssel szerzett saját tapasztalatok megosztása és az eljárás bemutatása.

Anyag és módszer: A Pécsi Tudományegyetem Urológiai Klinikáján három gyógyszeres kezelésre refrakter, alsó húgyúti tüneteket mutató betegnél végeztünk - elözetes vizelési naplókitöltés, alap urológiai státusz felmérés és urodinámias vizsgálatok után - Urgent ${ }^{\circledR P C}$ Neuromodulációs Rendszerrel perkután nervus tibialis posterior stimulációt. A beavatkozást heti egy alkalommal, 30 perces kezelést alkalmazva, 12 héten át alkalmaztuk. A 12 hetes kezelési periódus után vizeletüledék-vizsgálat, ultrahangkontroll, reziduális vizeletmeghatározás, ismételt vizelési napló kitöltése és a kezelés elött urodinamikai eltérést mutató betegnél urodinámias kontrollvizsgálat történt. Eredmények: Vizelési napló alapján mindhárom betegünknél, mind az inkontinens epizódok, mind vizelési gyakoriság, mind a sürgető késztetés, mind az éjszakai vizelések szempontjából javulást észleltünk. Az urodinámias vizsgálat során érdemi változást az objektív paraméterek tekintetében nem tudtunk igazolni. Betegek a kezelést jól tolerálták, szövődményt nem észleltünk.

Megbeszélés: Mind az irodalmi adatokat, mind jelen, igen kis esetszámú kezdeti saját adatainkat is figyelembe véve megállapitható, hogy a perkután nervus tibialis posterior stimuláció hatékony, minimálisan invaziv, jól tolerált, biztonságos kezelése a túlműködő hólyagszindrómának.

\section{KULCSSZAVAK}

TÚLMÜKÖDÖ HÓLYAG, DETRUZOR TÚLMÜKÖDÉS, NEUROMODULACIÓ

\section{Percutaneous tibial nerve stimulation (PTNS) in the treatment of the overactive bladder syndrome: first Hungarian experiences}

\section{SUMIMARY}

Introduction: Overactive bladder is a syndrome of multiple etiological origins. Regarding relevant guidelines second (third) line invasive treatment are indicated in cases, refractory to standard medical treatment. Percutaneous tibial nerve stimulation among the different neuromodulations is one of the treatments of choice as second line therapy. Regarding recent literature data, the procedure is effective in the treatment of overactive bladder. The aim of this current paper is to introduce the technique, and - first in Hungarian literature - to demonstrate the preliminary own data gained with it.

Material and method: Three patients with symptoms of overactive bladder, refractory to standard medical treatment were treated. Pre-treatment bladder diaries were obtained, basic urological investigations, and urodynamics were performed. With Urgent ${ }^{\circledR P C}$ Neuromodulation System 30 minutes' treatments on weekly basis for 12 weeks were performed. After the fulfilled treatment urine test, ultrasound control was done and repeated bladder diary was asked. By the patient with pathological urodynamic findings prior the treatment, a control urodynamics was performed as well.

Results: Based on the bladder diaries all patients had an improvement regarding incontinent episodes, frequency and urgency. The control urodynamics could not prove significant change compared the findings seen prior the treatment. The treatments were well tolerated, no complication was observed. Conclusion: Based on relevant literature data and based on our limited own experience, the percutaneous tibial nerve stimulation is an effective, minimally invasive safe treatment of the overactive bladder

\section{KEYWORDS}

OVERACTIVE BLADDER, OVERACTIVE DETRUSOR, NEUROMODULATION 


\section{Bevezetés}

A túlmúködő hólyagszindróma (Overactive Bladder - OAB) számos okra visszavezethető tünetegyüttes, az általánosan elfogadott definíciója szerint: sürgető vizelési késztetés inkontinenciával, vagy anélkül, általában gyakori vizeléssel és nocturiával, kimutatható patológiai ok, infekció nélkül $(1,2)$. Amennyiben a tünetcsoportnak a hátterében a detruzor izomzat diszfunkciójának objektív, urodinamikailag is kimutatható túlmúködése áll, beszélünk detruzor túlmúködésről (detrusor overactivity - DO) (3).

Az európai és amerikai irányelvek nem egységesek abban a tekintetben, hogy mit tekinthetünk az OAB/DO első, másod-, illetve harmadvonalbeli kezelésnek. Míg az Európai Urológus Társaság másodvonalbeli kezelésnek csak az invazív beavatkozásokat tartja, addig az Amerikai Urológusok Társasága ugyanezen beavatkozásokat harmadvonalbeli kezelésként tartja számon (4, 5). Ide tartoznak a különböző neuromodulációs eljárások és a botulinum toxin intravesicalis injektálása. A különböző irányelvek egységesek abban a tekintetben, hogy az életmódbeli változásokra, viselkedésterápiára és gyógyszeres terápiára refrakter esetekben javasolt ezeknek az invazív kezeléseknek az alkalmazása. További igény lehet az invazív beavatkozásokra, a standard gyógyszeres kezelés során tapasztalt kedvezőtlen mellékhatásprofil melletti alacsony adherencia és perzisztencia $(6,7)$.

Az OAB/DO kezelései közé tartoznak a neuromodulációs eljárások, ezek közül is legtöbb adattal a sacralis neuromodulációról (SNM) és a nervus tibialis posterior perkután (PTNS) stimulációjáról rendelkezünk.

\section{Perkután nervus tibialis stimuláció (ptns)}

A PTNS az alsó húgyúti tünetek befolyásolására alkalmazott, elfogadott, neuromodulációs terápia, amelynek során a sacralis idegfonatokat minimál invazív módon, a nervus tibialis posterioron keresztüli neurális úton lehet elérni (8). Az irodalmi adatokat áttekintve a kezelés hatásosabbnak bizonyult mind placebónál, mind antimuscarin gyógyszerekkel szemben. A tanulmányok alapján, az inkontinens epizódok számát, használt

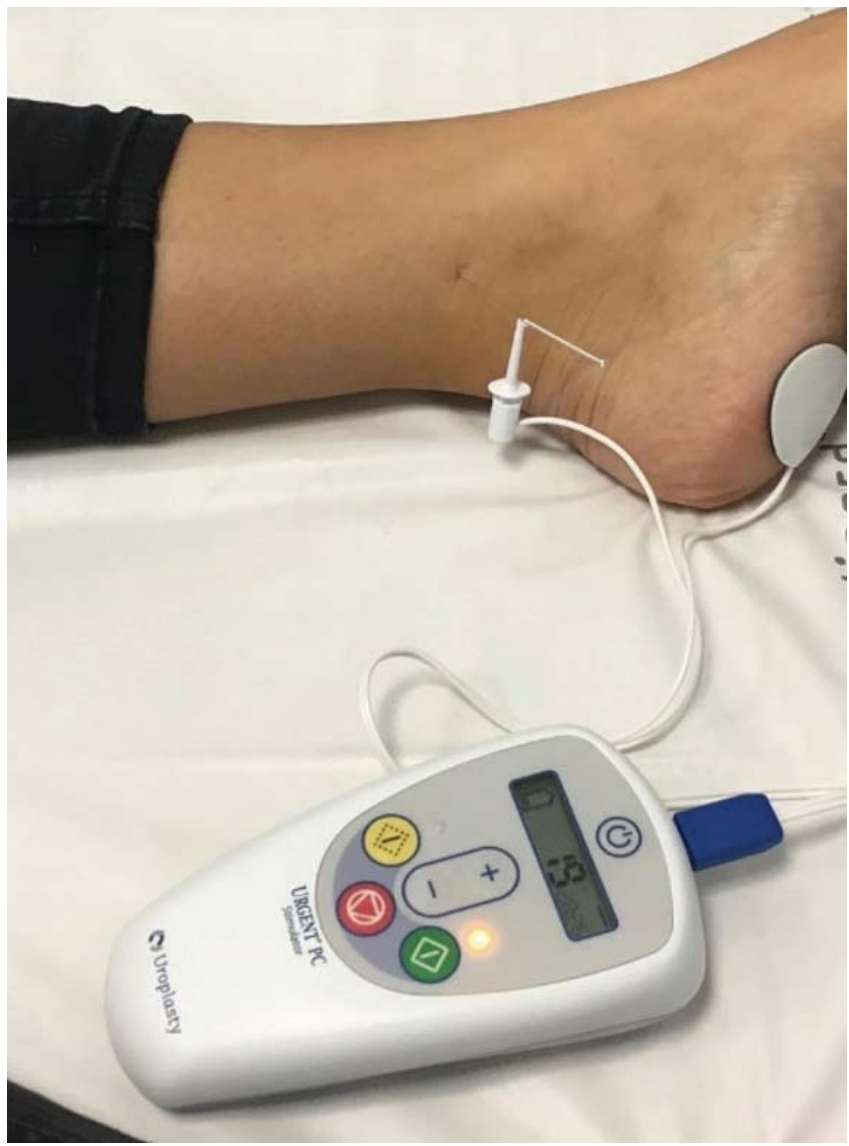

\section{1. Ábra: Az Urgent ${ }^{\circledR} P C$ Neuromodulációs Rendszer} HASZNÁLAT KÖZBEN

betétek számát, vizelési gyakoriságot, hólyagkapacitást figyelembe véve, a kezelés hatékonysága 54\%-79\% közötti. Lényeges mellékhatást egyik tanulmány sem rögzített (9-12).

\section{Anyag és módszer}

Tudomásom szerint, PTNS-sel szerzett, magyarországi saját adatok nem állnak rendelkezésre, ezért egy kezdeti vizsgálatot

\section{1. tÁBlÁZAT: A KEZELÉSBe beVont betegeK adATAI}

\begin{tabular}{|c|c|c|c|c|c|c|}
\hline Beteg & Életkor & $\begin{array}{l}\text { Alsó húgyúti } \\
\text { tünetek }\end{array}$ & $\begin{array}{c}\text { Megelóző } \\
\text { kezelés }\end{array}$ & $\begin{array}{l}\text { Vizelet- } \\
\text { üledék }\end{array}$ & Cisztoszkópia & Urodinámias eltérés \\
\hline Sz.A. & 60 év & sürgető késztetés & $\begin{array}{l}\text { oxybutinin, } \\
\text { solifenacin }\end{array}$ & negatív & negatív & $\begin{array}{c}\text { fokozott hólyagér- } \\
\text { zékelés, egyebekben } \\
\text { negatív }\end{array}$ \\
\hline B.M & 72 év & $\begin{array}{l}\text { gyakori vizelési inge- } \\
\text { rek, sürgető késztetés, } \\
\text { inkontinencia }\end{array}$ & $\begin{array}{l}\text { solifenacin, } \\
\text { trospium }\end{array}$ & negatív & negatív & $\begin{array}{l}\text { detruzor túlmúködés, } \\
\text { detruzor túlmúködést } \\
\text { követő inkontinencia }\end{array}$ \\
\hline N.B. & 23 év & $\begin{array}{l}\text { gyakori vizelési inger, } \\
\text { sürgető késztetés, } \\
\text { hólyagtájéki fájdalom }\end{array}$ & $\begin{array}{l}\text { solifenacin, } \\
\text { hialuronsav }\end{array}$ & negatív & - & $\begin{array}{c}\text { fokozott hólyagér- } \\
\text { zékelés, egyebekben } \\
\text { negatív }\end{array}$ \\
\hline
\end{tabular}


végeztünk (pilot study), a jól definiált irodalmi adatok megerősítésére. A Pécsi Tudományegyetem Urológiai Klinikáján 2017 novembere és 2018 áprilisa között, három, korábbi konzervatív terápiára refrakter, alsó húgyúti tünetektől szenvedő hölgyet vontunk be a vizsgálatba. Beválasztás előtt vizelési naplókitöltés, alap urológiai státusz felmérés és urodinámiás vizsgálatok történtek. A betegek karakterisztikáját az 1. táblázat foglalja össze.

A három beteg közül egynél volt urodinamikailag igazolható detruzor túlmúködés, de mindhárom beteg vizelési naplója jelentős alsó húgyúti tünettant tükrözött (2. táblázat). UH-vizsgálat felső húgyúti eltérést nem igazolt egyik esetben sem, vizeletüledék-vizsgálat és bakteriológiai tenyésztés negatív eredményt hozott minden esetben. Szignifikáns reziduális vizelet egyik esetben sem volt kimutatható.

A beavatkozást az Urgent ${ }^{\circledR} P C$ Neuromodulációs Rendszerrel, 0,22G×40 mm-es tű elektródával végeztük. A belső bokacsont felett 3 harántujjal, a tibia éle alatt 1 harántujjal 60 fokos szögben cranial felé irányulva, mintegy $2 \mathrm{~cm}$ mélyen helyeztük el a tǔelektródát, míg a felszíni elektródát a talpon helyeztük el (1. ábra). Az irodalmi adatok alapján általánosan elfogadott protokoll szerint, heti egy alkalommal, 30 perces kezelést alkalmaz-

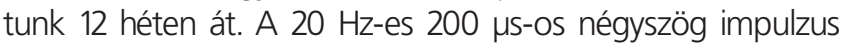
áramerősségét minden kezelés során, individuálisan állítottuk be. Az áramerősség mértékét vagy a lábon észlelt izomválasz, vagy a beteg által jelzett, lábon felfelé futó fájdalomérzet határozta meg. Az általunk használt áramerősség 2,5-9 mA között változott.

A 12 hetes kezelési periódus után vizeletüledék-vizsgálat, ultrahangkontroll, reziduális vizeletmeghatározás és a kezelés előtt urodinamikai eltérést mutató betegnél urodinámiás kontrollvizsgálat és ismételt vizelési napló kitöltése történt.

\section{Eredmények}

Mindhárom beteg egyértelmű szubjektív javulásról számolt be. Ultrahangvizsgálat alapján felső húgyúti eltérést, szignifikáns reziduális vizeletet egyik betegnél sem észleltünk, vizeletüledék-vizsgálat minden esetben negatív volt. Vizelési napló alapján mind az inkontinens epizódók, mind vizelési gyakoriság, mind a sürgető késztetés, mind az éjszakai vizelések szempontjából javulást észleltünk (3. táblázat). Az urodinámiás vizsgálat során érdemi változást az objektív paraméterek tekintetében nem tudtunk igazolni. Betegek járóbeteg-rendelés keretében, jól tolerálták a kezelést (2. ábra). Szövődményt nem észleltünk.

\section{Megbeszélés}

A túlmúködő hólyagszindróma/detruzor túlmúködés jelentős probléma, nagyszámú beteget érint. Bár számos elsővonalbeli kezelési lehetőség áll rendelkezésre, sok esetben a betegek ezekre nem, vagy kevésbé reagálnak, terápiát megszakítják. A másodvonalbeli kezelések közül, talán a legkevésbé invazívnak a PTNS tekinthető. Közleményem célja természete-

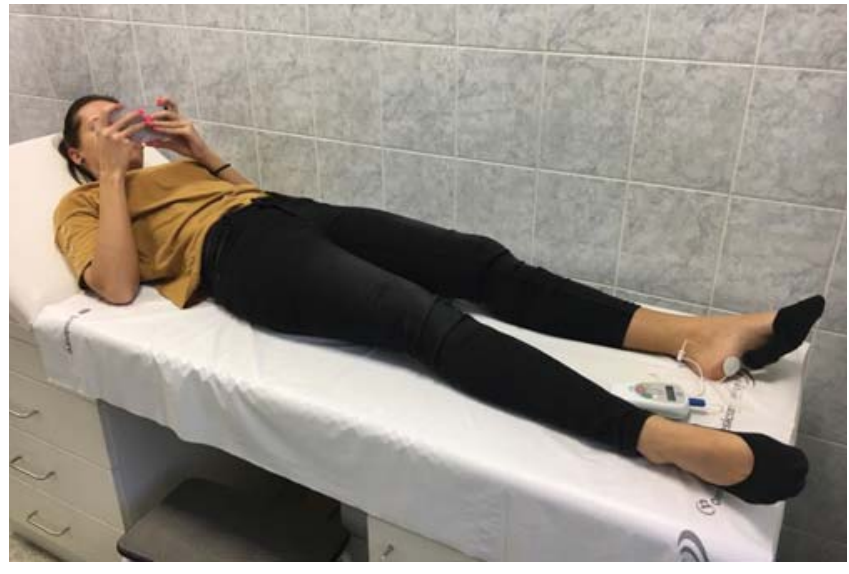

2. ÁBRA: JÁRÓBETEG-RENDELÉS KERETÉBEN JÓL TOLERÁLHATÓ A KEZELÉS

2. TÁBLÁZAT: A BETEGEK KEZELÉS ELŐTTI VIZELÉSI NAPLÓJA

\begin{tabular}{|c|c|c|c|c|c|}
\hline & $\begin{array}{c}\text { Frek- } \\
\text { ven- } \\
\text { cia }\end{array}$ & Frakciók & $\begin{array}{c}\text { Sürgető } \\
\text { készte- } \\
\text { tés }\end{array}$ & $\begin{array}{l}\text { Noc- } \\
\text { turia }\end{array}$ & $\begin{array}{l}\text { Inkonti- } \\
\text { nencia }\end{array}$ \\
\hline SZ.A. & $\begin{array}{c}\text { 8-10/ } \\
\text { nap }\end{array}$ & $\begin{array}{l}40-360 \mathrm{ml} \\
\text { átlag } 180 \mathrm{ml}\end{array}$ & $8 x$ & $1 \times$ & - \\
\hline B.M. & $\begin{array}{c}\text { 17-18/ } \\
\text { nap }\end{array}$ & $\begin{array}{l}30-250 \mathrm{ml} \\
\text { átlag } 110 \mathrm{ml}\end{array}$ & $10-12 x$ & $4-5 x$ & $1-2 x$ \\
\hline N.B. & $\begin{array}{c}\text { 14-16/ } \\
\text { nap }\end{array}$ & $\begin{array}{l}125-280 \mathrm{ml} \\
\text { átlag } 175 \mathrm{ml}\end{array}$ & $14-16 x$ & $1 x$ & - \\
\hline
\end{tabular}

\section{TÁBLÁZAT: A BETEGEK KEZELÉS UTÁNI VIZELÉSI NAPLÓJA}

\begin{tabular}{|c|c|c|c|c|c|}
\hline & $\begin{array}{l}\text { Frek- } \\
\text { ven- } \\
\text { cia }\end{array}$ & Frakciók & $\begin{array}{c}\text { Sürgető } \\
\text { készte- } \\
\text { tés }\end{array}$ & $\begin{array}{l}\text { Noc- } \\
\text { turia }\end{array}$ & $\begin{array}{l}\text { Inkonti- } \\
\text { nencia }\end{array}$ \\
\hline SZA. & $\begin{array}{l}6-8 / \\
\text { nap }\end{array}$ & $\begin{array}{c}70-420 \mathrm{ml} \\
\text { átlag } 210 \mathrm{ml}\end{array}$ & $4-5 x$ & - & - \\
\hline B.M. & $\begin{array}{l}\text { 13-14/ } \\
\text { nap }\end{array}$ & $\begin{array}{c}50-320 \mathrm{ml} \\
\text { átlag } 190 \mathrm{ml}\end{array}$ & $4-6 x$ & $2 x$ & - \\
\hline N.B. & 8/nap & $\begin{array}{l}165-410 \mathrm{ml} \\
\text { átlag } 250 \mathrm{ml}\end{array}$ & $8 x$ & - & - \\
\hline
\end{tabular}

sen nem statisztikai véleményalkotás volt, ez a rendkívül kis esetszám miatt nem lehetséges. Célom elsősorban ennek a jól definiált és vizsgált kezelési módnak a bemutatása, valamint az ezzel az eljárással szerzett elsődleges tapasztalatink megosztása. Limitált esetszámunk alapján is tapasztalhattuk a kezelés hatékonyságát és biztonságos kivitelezhetőségét. Figyelemfelkeltő, hogy az urodinamikailag igazolt detruzor diszfunkció esetében az objektív paraméterek tekintetében nem sikerült szignifikáns változást igazolni, ugyanakkor ennél 
a betegnél is a szubjektív értékelés és a vizelési napló alapján javulást láttunk. Érdekes megfigyelés volt a kezelések során mind a betegek között, mind az egyes betegeknél a kezelések között, az effektív áramerősség értékének szórása. Általánosságban megállapítható volt, hogy egyes betegeknél mindig alacsonyabb érték volt hatásos, másiknál mindig magasabb, és az is látható volt, hogy egyfajta "hozzászokást" láttunk, a kezelési számok előrehaladtával magasabb értékek voltak hatékonyak szinte kivétel nélkül. llyen adatok elemzésére utaló irodalmi összegzést nem találtam, ez irányba tudomásom szerint vizsgálatok nem történtek. Későbbiekben nagyobb esetszámú beteganyagon, prospektív vizsgálata szükséges ezen adatoknak.

\section{Következtetések}

Mind az irodalmi adatokat, mind jelen, igen kis esetszámú kezdeti saját adatainkat is figyelembe véve megállapítható, hogy a perkután nervus tibialis posterior stimuláció hatékony, minimálisan invazív, jól tolerált, biztonságos kezelése a túlmúködő hólyagszindrómának. A kezelést érdemes még gyógyszeres kezelés eredménytelensége esetén is alkalmazni.

\section{Köszönetnyilvánítás}

A kezelésekhez az Urgent ${ }^{\circledR} P C$ Neuromodulációs Rendszert és az elektródákat a Fempharma Kft. biztosította.

\section{Irodalom}

1. Haylen $B T$, de Ridder D, Freeman RM, et al. An International Urogynecological Association (IUGA)/International Continence Society (ICS) Joint Report on the Terminology for Female Pelvic Floor Dysfunction. Neurourol Urodyn 2010; 29: 4-20.

2. Pytel Á. A vizelet tárolási zavarok terminológiája. In Inkontinencia, Diagnosztika, terápia, rehabilitáció Szerk: Katona F, Hamvas A, Klauber A. Medicina; 2013. p. 83-85.

3. Gajewski JB, Schurch B, Hamid R, et al. An International Continence Society (ICS) Report on the terminology for adult neurogenic lower urinary tract dysfunction (ANLUTD) Neurourol Urodyn 2018; 37: 11521161. https://doi.org/10.1002/nau.23397

4. Burkhard FC, Bosch JLHR, Cruz F, et al. EAU Guidelines on urinary incontinence in adults. Edn. presented at the EAU Annual Congress London 2017. 978-90-79754-91-5. Publisher: EAU Guidelines Office. Place published: Arnhem, The Netherlands. 2017.

5. Gormley EA, Lightner DJ, Faraday M, et al. Diagnosis and treatment of overactive bladder (non neurogenic) in adults: AUAJSUFU guideline amendment. J Urol 2015; 193(5): 1572-1580. https://oi.org/10.1016/j. juro.2015.01.087

6. Benner JS, Nichol MB, Rovner ES, et al. Patient reported reasons for discontinuing overactive bladder medication. BJU Int 2010; 105(9): 1276-1282. https://doi.org/10.1111/.1464-410X.2009.09036.x

7. Veenboer PW, Bosch JL. Long term adherence to antimuscarinic thera- py in everyday practice: a systematic review. J Urol 2014; 191(4): 10031008. https://doi.org/10.1016/j.juro.2013.10.046

8. Tutolo M, Ammirati E, Heesakkers J, et al. Efficacy and safety of sacral and percutaneous tibial neuromudulation in non neurogenic lower urinary tract dysfunction and chronic pelvic pain: A systematic review of the literature. Eur Urol 2018; 73: 406-418. https://doi.org/10.1016/j. eururo.2017.11.002

9. Peters KM, MacDiarmid SA, Wooldridge LS, et al. Randomized trial of percutaneous tibioal nerve stimulation versus extended-release toterodine: results from the overactive bladder innovative therapy trial. J Urol 2009; 182: 1055-1061. https://doi.org/10.1016/j.juro.2009.05.045

10. PetersKM, Carrico DJ, Perez-Marrero RA, et al. Randomized trial of percutaneous tibial nerve stimulation versus sham efficacy in the treatment of overactive bladder syndrome: results from the SUmiT trial. J Urol 2010; 183: 1438-1443. https://doi.org/10.1016/j.juro.2009.12.036

11. Finazzi-Agro E, Petta F, Sciobica F, et al. Percutaneous tibial nerve stimulation effect is not to due to a placebo effect: $A$ randomized double-blind, placebo controlled trial. J Urol 2010; 184: 2001-2006. https:/ doi.org/10.1016/j.juro.2010.06.113

12. Gungor Ugurlucan F, Onal M, Aslan E, et al. Comparison of the effects of electrical stimulation and posterior tibial nerve stimulation in the treatment of overactive bléadder syndrome. Gynecol Obstet Invest 2013; 75: 46-52. https://doi.org/10.1159/000343756

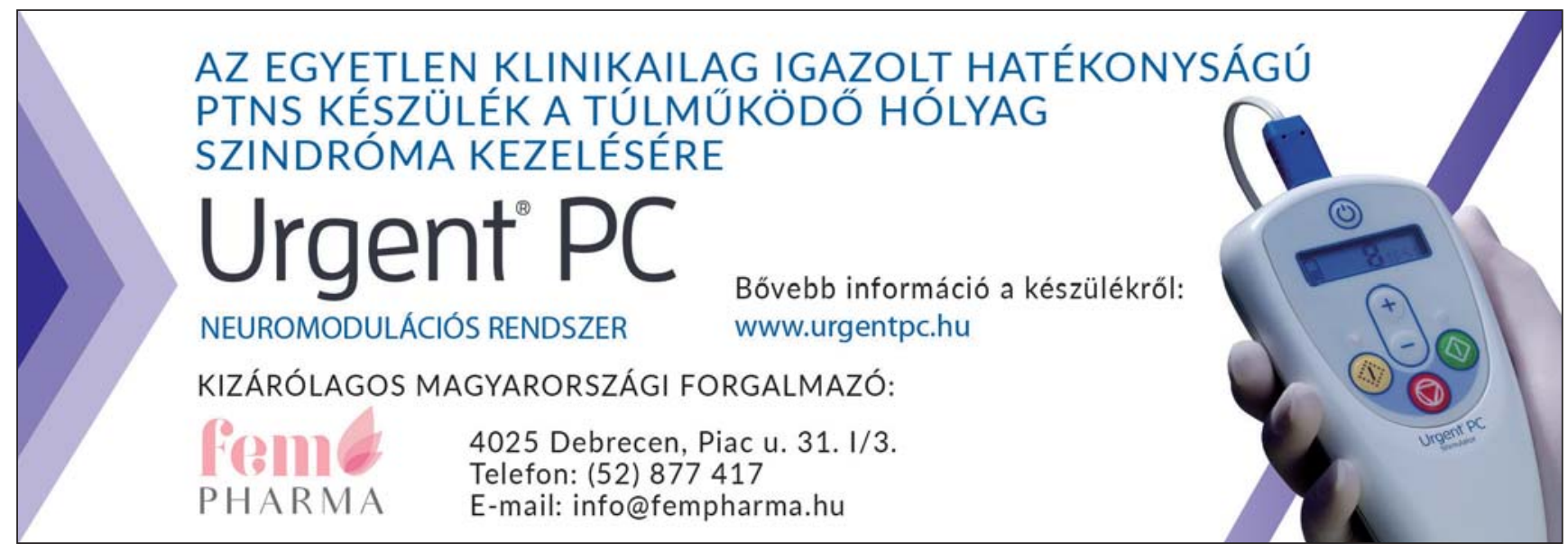

